Lyme arthritis has been reported so far only in the USA ${ }^{45}$; this study, however, suggests that it may also be found in Europe, and hence European doctors should be on the look out for new cases. It may frequently be missed since the onset of the arthritis may occur several months after the skin lesion has disappeared. ${ }^{4}$

${ }^{1}$ Aeschlimann A. Ixodes ricinus, Linné, 1758 (Ixodoidea; Ixodidae) Essai préliminaire de synthèse sur la biologie de cette espèce en Suisse. Acta Trop (Basel) 1972;29:321-40.

2 Golding D, Champion RH, Rook A, Roberts SOB. Erythema chronicum migrans in Britain. $\mathrm{Br}$ Med $\mathcal{F}$ 1978;ii:1087.

${ }^{3}$ Steere AC, Malawista SE, Snydan DR, Andiman WA. A cluster of arthritis in children and adults in Lyme Connecticut (abstract). Arthritis Rheum 1976;19:824.

4 Steere AC, Malawista SE, Hardin JA, Ruddy S, Askenase PW, Andiman WA. Erythema chronicum migrans and Lyme arthritis. The enlarging clinical spectrum. Ann Intern Med 1977;86:685-98.

${ }^{5}$ Steere AC, Malawista SE. Cases of Lyme disease in the United States locations correlated with distribution of Ixodes dammini. Ann Intern Med $1979 ; 91: 730-3$.

(Accepted 19 fune 1981)

Rheumatology and Rehabilitation Centre, University Hospital, 1011 Lausanne, Switzerland

J C GERSTER, MD, consultant rheumatologist

SERGE GUGGI, MD, practitioner in internal medicine

Dermatology Clinic, University Hospital, 1011 Lausanne, Switzerland

HENRI PERROUD, MD, practitioner in dermatology

RENE BOVET, MD, senior registrar

\section{A case in favour of Poncet's disease}

Poncet ${ }^{1}$ described a polyarthritis in the acute stage of extra-articular tuberculosis which eventually resolved without residual joint damage. This condition has been considered to be an allergic polyarthritis. ${ }^{2}$ Several case reports have been published, ${ }^{2-4}$ but there remains some controversy over whether the association is real or fortuitous. Summers and Jayson ${ }^{5}$ found no evidence of the condition in a detailed survey of 50 patients with active or treated tuberculosis, and they suggested that previous descriptions may have been due to chance.

I describe a patient in whom there was a strong temporal relation between episodes of polyarthritis and the presence of active tuberculosis.

\section{Case report}

A 34-year-old black Zambian man presented in February 1981 complaining of an unproductive cough, loss of appetite and wcight, and night sweats for about six weeks. He also complained of aching and stiffness of his wrists, elbows, ankles, and knees, and slight swelling of his knees for about eight weeks. The joint symptoms were present throughout the day but tended to be worse in the morning. Physical examination showed him to be reasonably well-nourished with a temperature of $38.1{ }^{\circ} \mathrm{C}$ and pulse of $94 / \mathrm{min}$. No rash was present. On auscultation of the chest coarse crepitations were heard over the right base posteriorly. There was a full range of movement of all the joints, though some pain was caused by full extension and flexion of the wrists, and slight periarticular swelling of the knees was found. The knees and wrists were warmer to touch than the surrounding skin; no joint effusions were present. A chest radiograph showed patchy shadowing at the right lower zone and right apex, fibrotic changes at the left apex, and specks of calcification in the left hilar lymph nodes. Sputum examination showed numerous acid-alcohol-fast bacilli, which on subsequent culture proved to be Mycobacterium tuberculosis. Haemoglobin concentration was $11.5 \mathrm{~g} / \mathrm{dl}$, erythrocyte sedimentation rate $96 \mathrm{~mm}$ in the first hour, and white cell count $8.2 \times 10^{9} / 1$. Radiographs of the wrists, elbows, knees and ankles showed no abnormality, and the result of a sheepcell agglutination test was negative. Pulmonary tuberculosis was diagnosed, and treatment was started with streptomycin $1 \mathrm{~g}$, thiacetazone $150 \mathrm{mg}$, and isoniazid $300 \mathrm{mg}$ daily. No specific treatment was given for the polyarthralgia, which was not severe. The patient's symptoms improved, and his sputum contained no $M$ tuberculosis after five weeks of treatment. The polyarthralgia and swelling of the knees improved progressively over about seven weeks, at which time his joints were normal on examination.

The joint symptoms had occurred on two previous occasions (1968 and
1974) when sputum-positive pulmonary tuberculosis had been diagnosed. The case notes confirmed that in 1968 he had complained of arthralgia of the wrists and knees, which preceded the diagnosis of tuberculosis by two months and which resolved within a month when antituberculous chemotherapy was given. In 1974 arthralgia and swelling of the wrists and knees began four months before tuberculosis was diagnosed, at which time a sterile clear effusion was present in the right knee joint. Radiographs of his wrists and knees had shown no abnormality, and the result of a sheep-cell agglutination test was negative. The joint symptoms and signs had resolved gradually over three months once antituberculous treatment was started.

$\mathrm{He}$ had not suffered polyarthralgia or joint swelling at any other time.

\section{Comment}

This patient suffered a low-grade polyarthritis each time he contracted pulmonary tuberculosis. Though the two conditions may have been associated by chance, this seemed unlikely in view of the recurrent association. The nature of the polyarthralgia and polyarthritis in this patient was similar to that described by Poncet. ${ }^{1}$ Symptoms of polyarthralgia and joint swelling preceded other symptoms of tuberculosis on all three occasions; it seems reasonable to suggest that tuberculosis should be included in the differential diagnosis of an unexplained polyarthralgia or polyarthritis.

${ }^{1}$ Poncet A. De la polyarthrite tuberculeuse déformante ou pseudorheumatisme chronique tuberculeux. Congrès Française de Chirurgie $1897 ; 1: 732-9$.

2 Bloxham CA, Addy DP. Poncet's disease: parainfective tuberculous polyarthropathy. Br Med F 1978; : 1590-1.

${ }^{3}$ Isaacs AJ, Sturruck RD. Poncet's disease-fact or fiction? Tubercle $1974 ; 55: 135-42$.

4 Greenwood BM. Polyarthritis in Western Nigeria. Ann Rheum Dis $1970 ; 29: 56-63$.

5 Summers GD, Jayson MIV. Does Poncet's disease exist? Rheumatol Rehabil 1980;19:149-50.

(Accepted 2 fune 1981)

Department of Medicine, University Teaching Hospital, Lusaka, Zambia

S C ALLEN, BSC, MRCP, senior registrar

THE MEDLAR TREE grows near the bigness of the Quince Tree, spreading branches reasonably large, with longer and narrower leaves than either the apple or quince, and not dented about the edges. At the end of the sprigs stand the flowers, made of five white, great, broadpointed leaves, nicked in the middle with some white threads also; after which comes the fruit, of a brownish green colour, being ripe, bearing a crown as it were on the top, which were the five green leaves; and being rubbed off, or fallen away, the head of the fruit is seen to be somewhat hollow. The fruit is very harsh before it is mellowed, and has usually five kernels within it. There is another kind hereof nothing differing from the former, but that it hath some thorns on it in several places, which the other hath not; and usually the fruit is small, and not so pleasant. They grow in this land, and flower in May for the most part, and bear fruit in September and October.

The fruit is old Saturn's, and sure a better medicine he hardly hath to strengthen the retentive faculty; therefore it stays women's longings: The good old man cannot endure women's minds should run a gadding. Also a plaister made of the fruit dried before they are rotten, and other convenient things, and applied to the reins of the back, stops miscarriage in women with child. They are powerful to stay any fluxes of blood or humours in men or women; the leaves also have this quality. The decoction of them is good to gargle and wash the mouth, throat and teeth, when there is any defluxions of blood to stay it, or of humours, which causes the pains and swellings. It is a good bath for women, that have their courses flow too abundant: or for the piles when they bleed too much. If a poultice or plaister be made with dried medlars, beaten and mixed with the juice of red roses, whereunto a few cloves and nutmegs may be added, and a little red coral also, and applied to the stomach that is given to casting or loathing of meat, it effectually helps. The dried leaves in powder strewed on fresh bleeding wounds restrains the blood, and heals up the wound quickly. The medlar-stones made into powder, and drank in wine, wherein some Parsley-roots have lain infused all night, or a little boiled, do break the stone in the kidneys, helping to expel it. (Nicholas Culpeper (1616-54) The Complete Herbal, 1850.) 